\title{
高性能ディジタル電流検出器
}

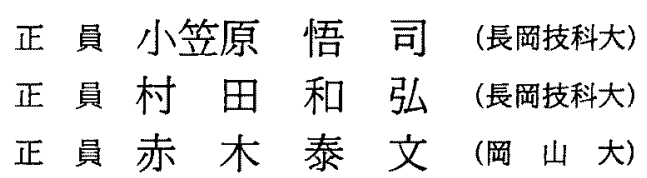

\section{A High Performance Digital Current Sensor}

Satoshi Ogasawara, Member, Kazuhiro Murata, Member (Nagaoka University of Technology), Hirofumi Akagi, Member (Okayama University)

The progress of microelectronics and microprocessors has advanced digitization of control circuits so that sensors have been expected to have digital output. Current sensors are basic in electrical drives, and the control accuracy depends on their performance. However, a current sensor using Hall-device has a non-linear error of $1 \%$. In order to solve this problem, a Hall-effect current sensor, or a so-called closed loop current sensor, has been developed, which is combined with a current transformer. The current of a secondary winding is compensated by the Hall-device so that the magnetic field in the toroidal core is kept at zero. In this case, the non-linear error is eliminated.

In this paper, a digital output current sensor of 12 bits is developed, which is a combination of a closed loop current sensor with a voltage comparator and a counter. As this circuit includes a nonlinear component such as the voltage comparator, the limit cycle caused by non-linearity is analyzed. It is described that the oscillation can be suppressed by linearization using a flush type A/ D converter of 4 bits.

キーワード : 電流検出器, ホール素子, 追従比較形 A/D 変換器, 自励振動

\section{1.はじめに}

近年, マイクロプロセッサあるいはその周辺素子な どの発達により，マイコンを用いたディジタル制御が 注目されており，モー夕制御分野においても制御回路 のディジタル化が進んでいる。制御回路がディジタル 回路の場合, 各種センサの出力もディジタル量である ことが望ましいが，現在のところディジタル出力の電 流検出器が開発された例は著者の知る限りないように 思われる。従って, 電流制御回路のディジタル化を行 う場合, アナログ電流検出器と $\mathrm{A} / \mathrm{D}$ 変換器を使用し なければならなかった。しかし, 高速・高精度のA/D 変換器は高価で, 検出精度はアナログ検出器の非線形 性に依存するなどの問題がある。

本論文では，電動機駆動などに用いることを想定 L, 㷌還形電流検出器と追従比較形 $\mathrm{A} / \mathrm{D}$ 変換器を組
合せたディジタル出力の電流検出器の構成法を提案す る。また, 追従比較形 $\mathrm{A} / \mathrm{D}$ 変換器は非線形系となる ことから非線形系特有の自励振動について解析し，線 形化により自励振動を抑制できることも併せて示す。

\section{2. 電流検出器の構成と動作原理}

〈2・1〉 オープンループ形電流検出器 従来から 広く用いられている電流検出器 DC-CT の構成を図 1 に示す。DC-CT は直流電流も検出できるよう, 被楖 定電流によってコア内に作られる磁束をホール素子を 用いて検出する(1)。本論文では,このようにフィード バックループをもたない電流検出器をオープンループ 形電流検出器と呼ら゙ことにする。通常, ホール素子は 約 $1 \%$ 程度の非線形性虽差をもつため, 図 1 のように ホール素子の出力を単に增幅し電流值とする場合, デ イジタル回路とのインタフェースに高分解能の A/D 


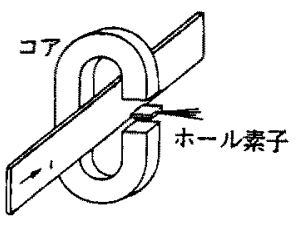

出典 ナナエレクトロニクスデータブック (1982 年)

図 1 オープンループ形電流検出器

Fig. 1. Open loop type current sensor.
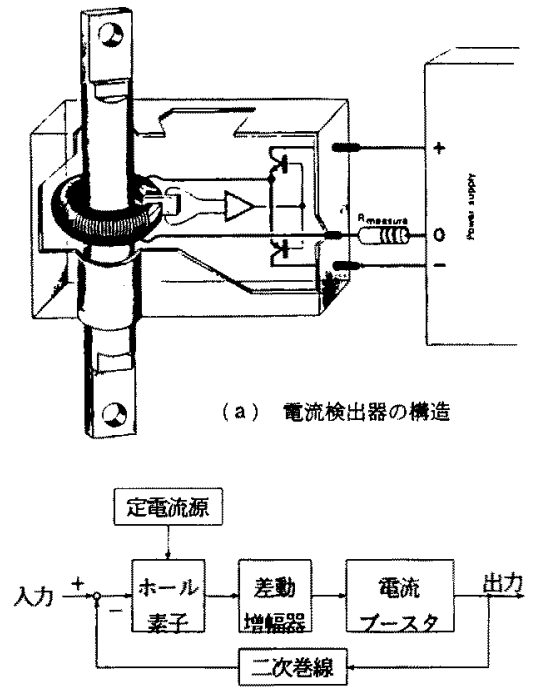

(b) 画游㛟出器の棌成

出典 LEM Data Sheets (Feb. 1985)

図 2 帰還形電流検出器

Fig. 2. Closed loop current sensor.

変換器を用いても，たかだか 7 bit 程度の精度しが得 ることができない。また，電流の振幅が大きい場合コ ア材の非線形性も無視できなくなるなどの問題があ る。更に，ホール起電力流磁界中を移動するキャリヤ がローレンツカを受けるために生じることから、ホー ル素子の積感度は温度に影響されやすく, 温度係数は 定電流方式で $0.02 \% /{ }^{\circ} \mathrm{C}$ 程度である。オープンループ 形電流検出器の場合, この温度変化の影響が電流值に 現れるという欠点もある。

〈2・2〉帰還形電流検出器 オープンループ形電 流榙出器の問題を解決するため, 図 2 に示されるよう に AC-CT とDC-CT を組合せ，ホール素子によって 㭘出された磁束をコア材に巻加れた二次巻線を通し て,フィードバックする電流検出器も開発されてい

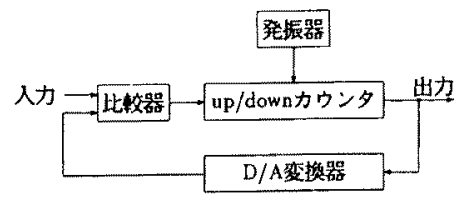

図 3 追従比較形 $\mathrm{A} / \mathrm{D}$ 変換器の構成

Fig. 3. Structure of $A / D$ converter using counter.

る(2)。本論文ては，このようにフィードバックループ をもつ電流検出器を㷌摆形電流検出器と呼ぷことにす る。

一般に, 変流器 (AC-CT) の二次巻線には, 被測 定電流の交流分に巻数比で割った電流が流れるが，直 流に対しては動作しない。従って, 帰還形電流検出器 の場合，直流分に対する磁束をホール素子によって検 出し，二次巻線に補償電流を流すことにより，直流㧈 よび交流電流の倹出を可能にしている。この場合, 構 成が複雑になる反面，コア中の磁束が常にゼロとなる ような電流が二次巻線に流れるため，ホール素子ある い情コア林の非線形性による誤差を除去できる。しか も, 温度による影響も受けにくく, 高精度な電流検出 に適している。

〈2・3〉新しいティジタル電流検出器の搆成と動作 原理本論文で提案する電流検出器では, アナログ 量をディジタル量に変換する手法として, 図 3 に示す 追従比較形 $\mathrm{A} / \mathrm{D}$ 变換の原理を用いている。追従比較 形 $\mathrm{A} / \mathrm{D}$ 変換器は, アップダウンカウンタの内容をデ イジタル信号入力とする D/A 変換器の出力電圧と, 被変挨入力電圧を比較器で比較し, 常に両方の電圧が 等しくなるようにアップダウンカウンタの内容を加堿 することによって A/D 変換するものである。この追 従比較形 $\mathrm{A} / \mathrm{D}$ 変換器は，カウンタおよび $\mathrm{D} / \mathrm{A}$ 変換 器を更に高ビットのものに換えることにより，容易に 高分解能が得られる。また，その構成の簡単さから安 価であるという利点を有する。入力がステッブ的に変 化する場合には適さないが，入力が連続で D/A 変換 器出力が入力に追従している場合, カウンタの内容が 入力に対するディジタル值を表す。

図 4 に, 提案する電流検出器の回路粠成を示す。こ れは, 原理的には図 2 の電流検出器と同様であるが, ループ内に図 3 に示される追従比較形の $\mathrm{A} / \mathrm{D}$ 変換器 を择入している点に特徽がある。ホール素子, 差動增 幅器およびコンパレータが図 3 の比較器に対応し, 磁 束をフィードバックするため $\mathrm{D} / \mathrm{A}$ 変換器の後に電圧一 電流変換执よび二次巻線が追加されているが, 基本的 


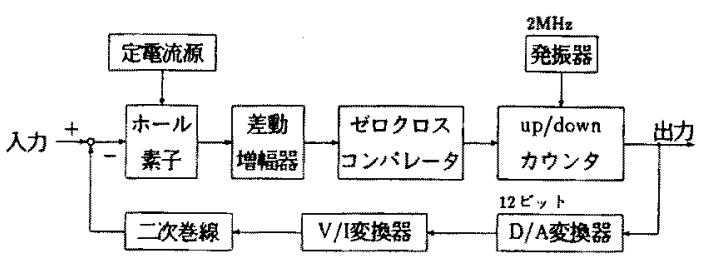

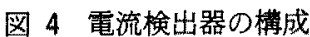

Fig. 4. Structure of developed current sensor.

には追従比較形 $\mathrm{A} / \mathrm{D}$ 変換器を構成している。また, コンパレータ,カウンタおよび $\mathrm{D} / \mathrm{A}$ 変換器がなけれ ば，図 2 に示した電流検出器と同じ構成となる。ここ で, 電圧-電流変換には電圧出力の增幅器に電流フィ ードバックをかけたものを用いている。增幅器の出力 インピーダンスが小さいため，DC-CT の変圧器作用 により電流フィードバックをほとんど動作させること なく二次電流を追従させることができ，電流フィード バックは誤差分の補償にのみ動作する。

図 3 の電流検出器は, 㷌還形電流検出器と同様に磁 束をフィードバックするため，ホール素子やコア材の 非線形性に影響されず高精度な電流検出が可能と考え られる。また，A/D変換に追従比較形を用いている ため, 安価で高分解能を容易に得ることが期待でき る。しかし, 被測定電流の変化の傾きに制限があるた め, 実際に適用する場合には注意を要する。

\section{3. ティジタル電流検出器の試作と検出特性}

〈3.1〉 ティジタル電流検出器の追従条件 図 3 の電流検出器では追従比較形 $\mathrm{A} / \mathrm{D}$ 変換器の原理を応 用しているため, 被測定電流の di/dt に制限がある。 そこで，電流検出器を設計するにあたり追徉比較形 $\mathrm{A} / \mathrm{D}$ 変換器が追従するための条件を求める。

カウンタは発振器1クロックてそその内容を1ずつ増 隇するため, 二次巻線に流れる電流の变化の傾き $\Delta$ は 1 bit 当たりの電流值と発振器の周波数によって決 まり，次式で得られる。

$$
\Delta= \pm \frac{I_{\max }}{2^{N-1}} \times f_{C L K}(\mathrm{ATT} / \mathrm{s})
$$

ここで， $I_{\max }, N, f_{C L K}$ はそれぞれ検出可能な電流の最 大值, $\mathrm{D} / \mathrm{A}$ 変換器のビット長, 発振器の周波数であ る。従って, 一次側の巻数を $n$ とすると次の不等式 が成り立つ場合 $A / D$ 変換器は追従可能となり, 高 速・高精度にディジタル值を得ることができる。

$$
n \times \frac{d i}{d t}<\Delta
$$

表 1 機器定数

\begin{tabular}{|c|c|}
\hline 定 格 出 力 & $2.2 \mathrm{~kW}$ \\
\hline 定 格 蒠 & $200 \mathrm{~V}$ \\
\hline 格 堂 流 & $9.5 \mathrm{~A}$ \\
\hline 対 数 & 2 \\
\hline 定 格 回 転 数 & $1,500 \mathrm{rpm}$ \\
\hline 滆れイダクタンス & $5 \mathrm{mH}$ \\
\hline インバー夕直流電代 & $300 \mathrm{~V}$ \\
\hline
\end{tabular}

Table 1. Parameters of tested machine.

表 2 諸 元

\begin{tabular}{|c|c|}
\hline 二次巻線の巻数 & 1,000 夕ーン \\
\hline $\mathrm{D} / \mathrm{A}$ 変接器棈度 & 12 bit \\
\hline D/A 変換器出力電压 & $\pm 10 \mathrm{~V}$ \\
\hline 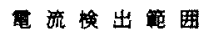 & $\pm 100 \mathrm{AT}$ \\
\hline
\end{tabular}

Table 2. Parameters of current sensor.

次に, 被測定電流の di/dt の最大値について考元 る。図 3 の電流検出器を電圧形 PWM インバータ・誘 導電動機駆動システムに用いる場合を考える。インパ 一夕の直流電圧を $V_{\mathrm{DC}}$, 誘䢘機の一次側拉よび二次僋 の漏れインダクタンスの和を $l$ とすると電流変化の傾 きは次式で与えられる(3)。

$$
\frac{d i}{d t}=\frac{V_{\mathrm{DC}}}{l}
$$

制御対象の誘導電動機の機器定数その他を表 1 に示 す。一次側㧍よび二次側の漏れインダクタンスの和は $5 \mathrm{mH}$ であり, 直流電圧 $300 \mathrm{~V}$ のインバータでこの電 動機を駆動する場合，(2)式より被測定電流の di/dt の絶対值は最大でも $60 \mathrm{~A} / \mathrm{ms}$ である。

〈3.2〉電流検出器の仕様 ディジタル電流検出 器を設計する場合, $\mathrm{A} / \mathrm{D}$ 変換の分解能, 二次巻線の 巻数, 電流の検出範国は自由に設定でき，今回は表 2 の定数を用いた。(1)，(2)式より発振器の周波数 $f_{C L K}$ は,

$$
f_{C L K}>1.23 \mathrm{MHz}
$$

となり、これより発振器の周波数を $2 \mathrm{MHz}$ とする と, 追従可能な被測定電流の di/dt は $97.7 \mathrm{AT} / \mathrm{ms}$ て ある。従って, 電流検出器の仕様は表 3 のようにな る。

〈3.3〉 検出特性 図 5 亿正弦波を入力し, 電流 検出器の動作試験を行った場合の検出波形を示す。写 真上が図 3 の電流榙出器の二次巻線に流れる電流波形 で, 写真下が電流プロープ(ソニーテクトロニクス A 6303）により測定した電流波形である。異常発振 し, 安定に検出していないことがわかる。また，ゼロ 
クロス近辺にひずみが見られる。

図 6 に入力を零とし，時間軸を拡大した場合の波形 を示す。図 6 では, 写真上が二次巻線の電流で写真下 がD/A 変換器出力である。電流は D/A 変換器出力 にほほ追従しており, 系全体で発振していることがわ かる。発振周波数は $5 \mathrm{kHz}$ と低く,また発振の振幅 は約 $0.5 \mathrm{~V}$ である。ディジタル值に換算すると $102_{(10)}$ になり，クロック周波数が $2 \mathrm{MHz}$ であることから， カウンタが $102_{(10)}$ カウントするのに要する時間は 51 的になる。これは発振周期と一致する。

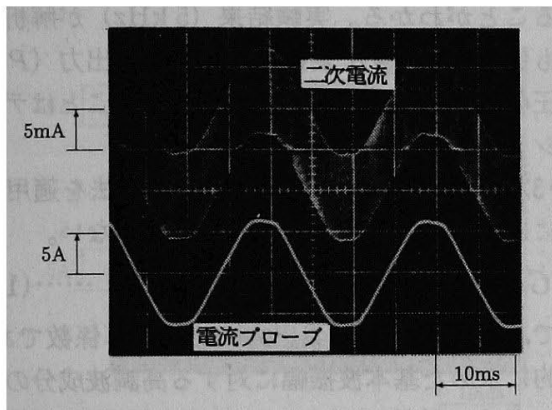

図 5 電流検出器の検出特性

Fig. 5. Current wave forms.

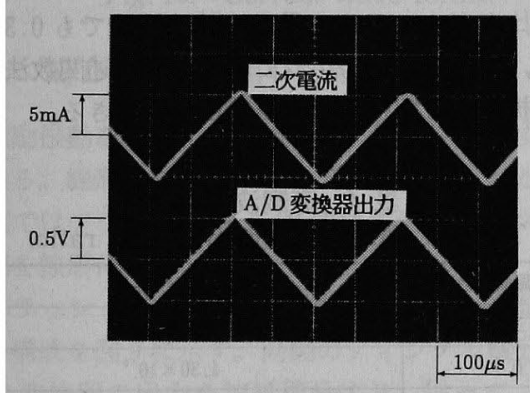

図 6 発振部分の拡大

Fig. 6. Wave forms of oscillation.

\section{4. 自励振動の理論解析}

図 3 で示した電流検出器は, 非線形性の強いコンパ レータがループ内にあり, また入力がなくても振動が 生じている。これょり, 二次電流に生じている振動は コンパレータの非線形性に起因する自励振動であると 考えられる。従って，記述関数法(4)(5)を用いて自励振 動の存在を確認する。

〈4・1〉解析モデル オペアンプを一次遅れと近 似し, ディジタル電流検出器をモデル化する場合, 系 の次数が高くなり, またカウンタ, D/A 変換器など の離散要素も含まれ解析が困難である。従って, 次の 仮定によりモデルを簡略化する。

（1）自励振動の周波数は差動増幅器の帯域に比べ 十分低い。

(2) D/A 変換器の分解能は十分高い。

この場合, 差動増幅器はゲイン $K_{1}$ の理想アンプ に, カウンタはゲイン $K_{i}$ の積分器に近似できる。図 3 の電流検出器の解析モデルを図 7 に示す。ここで, 図中の各記号は

$K_{1}:$ ホール素子・差動増幅器のゲイン

$K_{D A}: \mathrm{D} / \mathrm{A}$ 変換器のゲイン

$A: V / I$ 変換オペアンプの開放利得

$\omega_{2}: V / I$ 変換オペアンプの帯域

$L:$ 二次巻線のインダクタンス

$R: V / I$ 変換ダミーロードの抵抗值

である。コンパレータ出力が常に 1 の場合カウンタは 1 秒間にクロック周波数だけカウントすることにな る。従って，Ki $K_{i}$ はロック周波数と等価になる。な お，解析モデルではオペアンプの飽和を考慮していな い。

〈4・2〉解析結果 非線形部の記述関数を $G_{N}(a)$, 線形部の伝達関数を $G_{L}(s)$ とすると, 図 7 のシステム の特性方程式は,

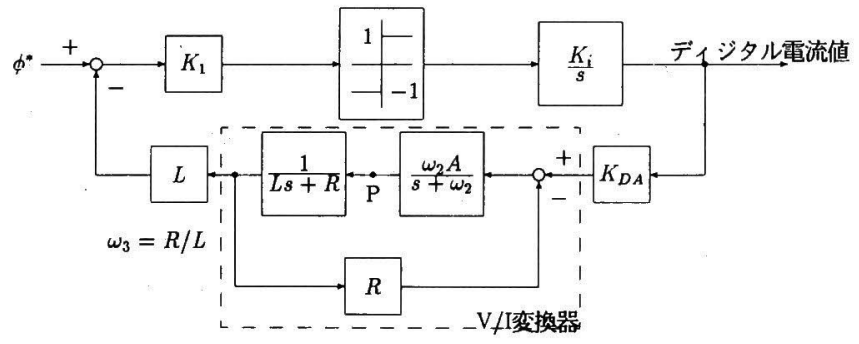

図 7 解析モデル

Fig. 7. Analyzed model. 


$$
1+G_{N}(a) G_{L}(s)=0
$$

となる。ここで，aは非線形要素に入力される正弦波 の振幅である。上式の $s$ を $\omega$ とおき，更に，

$$
G_{L}(j \omega) G_{N}(a)=U(a, \omega)+j V(a, \omega)
$$

とすると，

$$
\left.\begin{array}{l}
U(a, \omega)=-1 \\
V(a, \omega)=0
\end{array}\right\}
$$

を得る。線形部の伝達関数は, 図 7 より

$$
G_{L}=\frac{K}{s\left\{s^{2}+\left(\omega_{2}+\omega_{3}\right) s+\omega_{2} \omega_{3}(A+1)\right\}}
$$

ここで,

$$
K=A \omega_{2} K_{1} K_{i} K_{D A}
$$

である。また，コンパレータの記述関数は次式で表さ れる。

$$
G_{N}=4 / \pi a
$$

(7)，（8)式および(10)式より,

$$
\frac{4 K}{\pi a}+s^{3}+\left(\omega_{2}+\omega_{3}\right) s^{2}+\omega_{2} \omega_{3}(A+1) s=0
$$

となり， $s=j \omega$ と招き $\omega$ とaについて解くと，

$$
\begin{aligned}
& \omega= \pm \sqrt{\omega_{2} \omega_{3}(A+1)} \\
& a=\frac{4 K}{\pi \omega^{2}\left(\omega_{2}+\omega_{3}\right)} \cdots . .
\end{aligned}
$$

を得る。更に, 二次巻線に流れる電流の振幅 $I_{2}$ は次
式で表される。

$$
I_{2}=a / K_{1} L
$$

上式にオペアンプの規格あるいは電流検出器の仕様て 決まる定数などを代入することにより自励振動の振福 および周波数が求められる。実際に表 3 の值を代入す ると，

$$
\begin{aligned}
& I_{2}=1.93 \mathrm{~mA} \\
& f=40.1 \mathrm{kHz}
\end{aligned}
$$

であり、コンパレータの非線形性による自厉振動が存 在することがわかる。実験結果 $(5 \mathrm{kHz})$ が解析結果 よりも低いのは，V/I変換オペアンプの出力 $(P$ 点) で電圧の飽和が生じているためでこのことはディジ タルシミュレーションにより確認した。

〈4・3〉解析結果の検封 記述関数法を適用する ためには次式が成り立たたなければならない。

$$
\left|G_{L}(j k \omega)\right| a_{k} \ll\left|G_{L}(j \omega)\right| a_{1} \quad(k \neq 1)
$$

\begin{tabular}{|c|c|c|}
\hline 检 出 範 & 狸 & $\pm 100 \mathrm{AT}$ \\
\hline 模 出 粗 度 & 校 & $12 \mathrm{bit}$ \\
\hline dildtの最大随 & 随 & $97.7 \mathrm{AT} / \mathrm{ms}$ \\
\hline 二次 巻 線 & 線 & 1,000 ターン \\
\hline 発振器周波数 & w & $2 \mathrm{MHz}$ \\
\hline
\end{tabular}

ここで， $a_{k}$ 注非線形要素出力のフーリエ係数である。

\begin{tabular}{|c|c|}
\hline 复謂波次数 & 振培生 $(\%)$ \\
\hline 三次 & $3.65 \times 10^{-1}$ \\
\hline 五论 & $4.30 \times 10^{-2}$ \\
\hline 七次 & $1.09 \times 10^{-2}$ \\
\hline 九次 & $3.95 \times 10^{-3}$ \\
\hline
\end{tabular}
解析的に求めた基本波振幅に対する高調波成分の比を 図 8 に示す。破線で示されるのが自励振動の周波数 で，各高調波成分は基本波の $1 \%$ 以下であり，十分に 減衰している。自励振動周波数での基本波と高 調波の比を表 4 に示す。最大の第三調波でも $0.365 \%$ であり，従って本システムにおいては記述関数法を用 いて解析しても解析結果の䛊差は無視できる。
表 3 電流㭘出器仕様

Table 3. Specifications of current sensor.
表 4 高調波振幅比

Table 4. Harmonic components ratio.

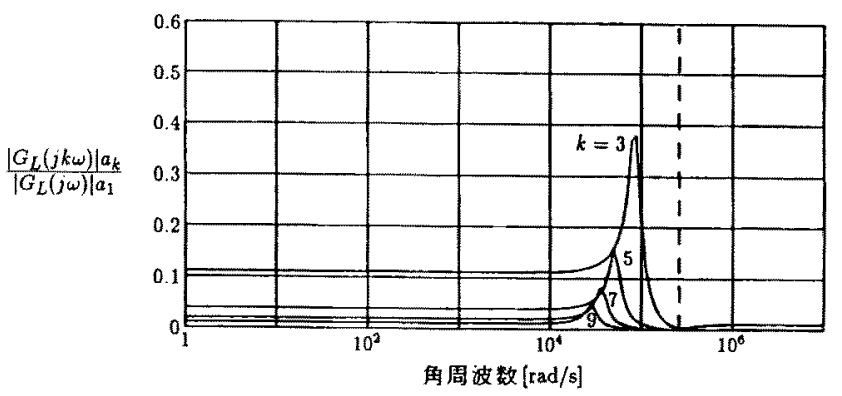

図 8 高調波振幅比

Fig. 8. Harmonic components ratio. 


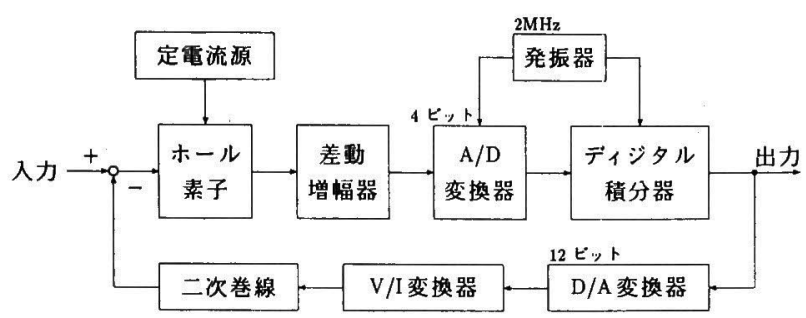

図 $9 \mathrm{~A} / \mathrm{D}$ 変換器を用いた構成

Fig. 9. Structure of current sensor using A/D converter.

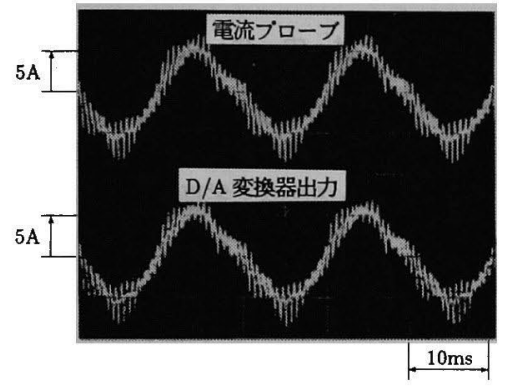

図 10 検出特性

Fig. 10. Current wave forms.

\section{A/D 变換器を用いた線形化}

自励振動を抑制するためには，系を線形化する必要 がある。線形化には幾つかの方法が考えられるが, 本 論文ではフラッシュ形 $\mathrm{A} / \mathrm{D}$ 変換器を用いコンパレー 夕部を線形化する。

フラッシュ形 $\mathrm{A} / \mathrm{D}$ 変換器を用いた場合の電流検出 器の構成を図 9 に示す。同図のディジタル積分器は, $\mathrm{A} / \mathrm{D}$ 変換器の出力を加算積分する。従って, 1クロ ックごとに $\mathrm{A} / \mathrm{D}$ 変換器の分解能に応じた範囲でディ ジタル出力を増減でき, 自励振動を抑制できると同時 にdildt の制限も大幅に緩和できる。例えば， $m$ ビッ トの A/D 変換器を用いたとすると，1クロックで加 算される最大值は $2^{m-1}-1$ であり，コンパレータを用 いた場合と比較すると, $2^{m-1}-1$ 倍の電流の変化に追 従できることとなる。

線形化を行ったディジタル電流検出器の検出特性を 図 10 に，また検出器仕様を表 5 にそれぞれ示す。被 測定電流は電圧形 PWM インバータで駆動した誘導 電動機の線電流である。写真上が電流プローブ (ソニ ーテクトロニクスA 6303）により測定した波形で, 下がディジタル電流検出器の D/A 変換器出力電圧で ある。なお, $\mathrm{D} / \mathrm{A}$ 変換器出力のスケールは電流值に
表 5 電流検出器の仕様

Table 5. Specifications of current sensor.

\begin{tabular}{c|c}
\hline 検 出 範 囲 & $\pm 50 \mathrm{AT}$ \\
\hline 検 出 精 度 & $12 \mathrm{bit}$ \\
\hline$d i / d t$ の最大值 & $391 \mathrm{AT} / \mathrm{ms}$ \\
\hline 二 次 巻 線 & 250 夕ーン \\
\hline 発振 器周 波数 & $2 \mathrm{MHz}$ \\
\hline
\end{tabular}

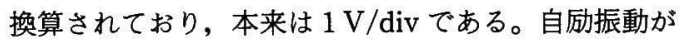
生じることなく安定に動作していることがわかる。

実験に用いたシステムでは被測定電流の $d i / d t$ が 60 $\mathrm{AT} / \mathrm{ms}$ 以下であり, 電流検出器が追従可能な被測定 電流の $d i / d t$ の最大值は $391 \mathrm{AT} / \mathrm{ms}$ であるため, 図 のようなリプルを含んた゚波形にもよく追従している。 また，クロック周波数が $2 \mathrm{MHz}$ であることから, 高

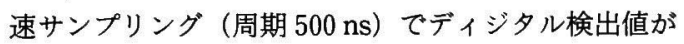
得られる。更に, di/dt の制限にも余裕があり, 一般 の電動機制御に図 9 の電流検出器を適用可能であると 考えられる。

従来のアナログ式帰還形電流検出器と $\mathrm{A} / \mathrm{D}$ コンバ 一夕を組合せた場合, 得られるディジタル信号の分解

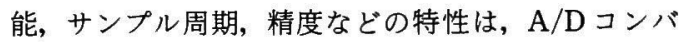
一夕の特性によりほほ決定される。しかし, 高速・高 分解能・高精度になればなるほど $\mathrm{A} / \mathrm{D}$ コンバータは 急激に高価となり, 電流検出器と A/D コンバータと のアナログインタフェース部の設計も難しくなる。こ れに対して提案したディジタル電流検出器の場合, 同 一のフィードバックループ内に電流検出器と $\mathrm{A} / \mathrm{D}$ 変 換器を構成しているために容易に高精度を維持でき, しかも高速・高分解能のディジタル信号を直接得られ る電流検出器を安価に構成できる。

6. むすび

誘導機のベクトル制御は，高精度なトルク制御を可 能にし, 従来の直流機はメンテナンスフリーである誘 
導機に置き換えられつつある。しかし, その制御精度 は電圧あるいは電流検出器の精度によって定まるとい っても過言ではない。電流検出器は, 以下の用件が要 求される(6)。

（1）非接触形であること

（2）直流から電流のリプルに追従する周波数特性 を有すること

（3） $0.1 \% \mathrm{FS}$ の精度を有すること

（4）温度依存性が小さいこと

更に, 制御回路がディジタル回路の場合, 各センサの 出力もディジタル量であることが望ましい。

本論文では, これらの背景をもとに，従来用いられ ていた帰還形電流検出器と追従比較形 A/D 変換器を 組合せたディジタル出力の電流検出器を開発した。し かし, 発振のため高い検出精度が得られなかった。こ の振動がコンパレータの非線形性に起因する自励振動 であることを理論解析により示すと共に，4ビットの フラッシュ形 $\mathrm{A} / \mathrm{D}$ 変換器を用いた線形化により抑制 できることを示した。線形化を行った場合, 分解能 $12 \mathrm{bit}$, 被測定電流の $d i / d t$ の最大值 $391 \mathrm{AT} / \mathrm{ms}$ 以 下, 検出範囲士50 AT, サンプリング周期 $500 \mathrm{~ns} の$ 仕様となることより，一般の電動機制御では本論文で 開発したディジタル電流検出器を使用でき, 電流制御 回路の全ディジタル化が可能であると考えられる。

(平成 3 年 5 月 20 日受付, 同 3 年 10 月 21 日再受付)

\section{文 献}

(1) ナナエレクトロニクス data-sheets.

(2) LEM DC-CT data-sheets.

（3）餅川・高橋：昭 58 電気学会東京支大, No. 202

(4) 平井：非線形制御システムの解析 (昭 61) オーム社

（5）水上：自動制御（昭 43）朝倉曹店

（6）園田, 他：「コアを用いた高速応答·高精度電流センサ」, 電 学論 D, 11177 (平 3-1)

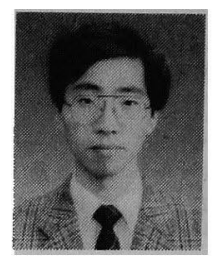

小笠原 悟 司（正員）

昭和 33 年 7 月 27 日生。 58 年 3 月長 岡技術科学大学大学院修士課程電気電子 システム工学専攻修了。同年 4 月同大学 工学部電気系助手, 現在に至る。工学博 士。パワーエレクトロニクスの研究に従事。計測自動制御 学会, パワーエレクトロニクス研究会, IEEE 会員。

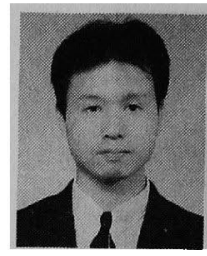
村田和 弘（正員）

昭和 38 年 8 月 31 日生。平成 3 年 3 月 長岡技術科学大学大学院修士課程電気電 子システム工学専攻修了。同年 4 月ヤマ 八発動機 (株) 入社，現在に至る。

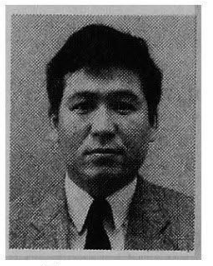

赤 木 泰 文（正員）

昭和 26 年 8 月 19 日生。 54 年 3 月東 京工業大学大学院博士課程電気工学尃攻 修了。同年 4 月長岡技術科学大学工学部 電気系助手, 59 年 10 月同助教授。62 年 3 月 12 月 MIT 客員研究員。平成 3 年 8 月岡山大学工学 部電気電子工学科教授。工学博士。電動機制御, 電力用ア クティブフィルタ, 高周波インバータなどの研究に従事。 $1980,1983,1990$ 年 IEEE/IAS Committee Prize Paper Award, 1991 年 IEEE/IAS Society Prize Paper Award, 60 年, 平成 3 年電気学会論文賞受賞。IEEE member。 